\title{
Implications of climate change for tourism and outdoor recreation: an Indiana, USA, case study
}

\author{
Jonathon Day ${ }^{1}$ (D) Natalie Chin ${ }^{2} \cdot$ Sandra Sydnor $^{1} \cdot$ Melissa Widhalm $^{3}$. \\ Kalim U. Shah ${ }^{4}$. Leslie Dorworth ${ }^{5}$
}

Received: 2 October 2020 / Accepted: 2 December 2021/Published online: 13 December 2021 (c) The Author(s), under exclusive licence to Springer Nature B.V. 2021

\begin{abstract}
In this case study, we examine a broad range of impacts on tourism and recreation based on projected changes to Indiana's climate. The direct impacts of climate change on Indiana include increases in the number of hot and extremely hot days each summer, fewer mild days, more rain, and less snow. Each direct impact will affect tourism and recreation. Additionally, a range of indirect impacts are anticipated, including climate-related changes in health issues, new infrastructure needs, changes in forests and other recreational areas, and shifting consumer attitudes toward travel and recreation. Although direct impacts are predictable, indirect impacts on the complex tourism system are harder to anticipate, and the tourism and recreation industry must build resilience to respond to future change. The paper concludes with recommendations for future study.
\end{abstract}

Keywords Tourism $\cdot$ Climate change $\cdot$ Resilience $\cdot$ Adaptation $\cdot$ Indiana

This article is part of the Topical Collection "The Indiana Climate Change Impacts Assessment", edited by Jeffrey Dukes, Melissa Widhalm, Daniel Vimont, and Linda Prokopy

Jonathon Day

gjday@purdue.edu

Natalie Chin

nchin5@aqua.wisc.edu

Sandra Sydnor

ssydnorb@purdue.edu

Melissa Widhalm

mwidhalm@purdue.edu

Kalim U. Shah

1kalshah1@gmail.com

1 School of Hospitality and Tourism Management, Purdue University, West Lafayette, IN, USA

2 University of Wisconsin Sea Grant Institute, Madison, WI, USA

3 Purdue Climate Change Research Center, Purdue University, West Lafayette, IN, USA

4 Biden School of Public Policy \& Administration, University of Delaware, Newark, USA

5 College of Engineering, Purdue University Northwest, Hammond, IN, USA 


\section{Introduction}

Even as the hospitality sector recovers from the significant impacts of the COVID19 pandemic, the spectre of climate change looms over the tourism industry. Climate change has been described as the primary challenge facing the global tourism industry (Davos Declaration: Climate Change and Tourism Responding to Global Challenges 2007). It will have wide-ranging impacts at all levels of the tourism system, from the global level to the destination-community level, as well as operational changes in individual businesses. Here, we examine the impacts of climate change on tourism, visitors, and outdoor recreation in the American Midwest state of Indiana. We examine the significance of the tourism and outdoor recreation sector in Indiana. We then examine the climate changes projected for Indiana for three future periods (2020s, 2050s, 2080s) and identify direct and indirect impacts of these changes on tourism in the state. The analysis integrates learning from a wide range of studies focused on indirect impacts of climate change, from impacts on forests and waterways to the anticipated policy implications of urban green infrastructure, energy, and water management. The case study provides important insights into the implications for tourism of a wide range of direct and indirect impacts. It highlights the gaps in our understanding of how climate impacts tourism.

\subsection{Tourism in Indiana}

Tourism and recreation are terms that encompass a wide range of activities in the tourism system, but each component's responses to climate change will vary, even when facing similar challenges. As such, this review examines the broad impacts of climate change on both tourism and recreation activities. Tourism and outdoor recreation are interrelated activities. Tourism is the activity undertaken by visitors, or people taking a trip away from their usual environment (UNWTO 2010). Of course, residents at a destination also use products and services catering to visitors, including outdoor recreational facilities. While discussions about tourism and visitors deal primarily with people traveling to a new location, recreation has no spatial or temporal boundaries (Nicholls 2012), and residents enjoy recreation within their community. The relationship between tourism and economic development is recognized, and in 2020, Indiana established the Indiana Destination Development Corporation (IDDC) to develop and market destination communities with a mandate to "attract and retain business, talent, students and visitors" (IOTD 2020b).

Tourism is a significant contributor to the Indiana economy. In 2019, almost 81 million people visited the state (IOTD 2020a). According to a 2019 study conducted for the Indiana Office of Tourism Development (IOTD), the tourism sector contributes $\$ 13.2$ billion to the state economy and directly employs more than 185,000 people. Tourism accounted for 5\% of all Indiana jobs, making it the 12th largest sectoral employer (RockportAnalytics 2020). Indiana is heavily dependent on domestic travel, with $99 \%$ of all visitors originating in the USA. Of all visitors to Indiana, $85 \%$ visit for leisure, with only $15 \%$ of visitors traveling for business (Rockport Analytics 2020). Indiana is known as the "Crossroads of America," and many visitors to Indiana travel by car from other parts of Indiana or neighboring states. Indiana has traditionally performed well in attracting young and family travelers. Baby boomers and Generation X traditionally have been important markets for the region (Garulski 2007), although Millennials' rise is changing visitor demographics. 
Indiana's geography provides visitors with several distinct landscapes to experience. The northern section of the state borders Lake Michigan. The Indiana Dunes, composed of both national and state parks, is one of the state's most popular destinations, attracting visitors from Chicago and Detroit, as well as Indiana residents. Indianapolis, the state capital and largest city, is a primary attraction for the state's central region, and rolling hills and forests characterize southern Indiana. The IOTD (Newman 2017) has categorized Indiana's tourism products and experiences as follows: culinary and agritourism, heritage and festivals, arts and culture, and outdoor recreation and sport. Indiana promotes culinary tourism, leveraging both a vibrant restaurant scene in the capital (Indianapolis) and throughout the state, with a focus on fresh, local ingredients. Indiana's wine trails provide visitors with quality experiences, allowing guests to enjoy vineyards' ambiance and sample local wines. Closely linked to Indiana's culinary scene is the state's growing agritourism sector. Indiana provides a range of agritourism experiences for visitors and tourists-from sophisticated modern farm experiences such as Fair Oaks Farms to historic farm recreation. Visitors can enjoy seasonal u-pick farm visits, corn mazes, and farmers' markets.

Indiana's Midwest heritage attracts numerous visitors from around the state and tourists from around the world. Indiana is Abraham Lincoln's childhood home and a terminus for the underground railroad, the network of safe havens used by African Americans to escape slavery in the Southern States. Other heritage attractions include the Indiana stained-glass trail and covered-bridge trails. Indiana's arts and cultural attractions are an important pillar of tourism. Indianapolis boasts several high-quality museums, including the world-famous Children's Museum. In addition, Indiana is home to more than 640 festivals, spread out over the state's 92 counties (ISFA 2018).

Sports are important attractions in Indiana. The Indianapolis 500 automobile race has international recognition, and the event attracts visitors from around the globe. Other spectator sports—including basketball, football, and baseball — at both the professional and college levels attract visitors and tourists. Indianapolis has proven capable of attracting major spectator events, including the Pan American Games and the Super Bowl. Additionally, Indiana has aggressively sought traveling teams, including those of youth sports. Several communities across the state have invested significantly in sports facilities for traveling teams. For example, the Grand Park Sports Campus in Westfield, Indiana, is a 400-acre facility with fields and an additional 300,000 square foot indoor turf space. The facility has 31 multipurpose fields suitable for soccer, football, rugby, field hockey, and lacrosse, as well as 26 baseball diamonds (VHC).

Outdoor recreation is also an essential component of the state's tourism profile. The state park system includes some of the state's most popular attractions. Hiking and camping are popular, particularly in the summer months. Trails for horseback riding and cycling are increasingly popular, and local communities are investing in the development of facilities to encourage these activities. Indiana's lakes provide opportunities to participate in water sports, including waterskiing, kayaking and canoeing, and fishing. Hunting and birdwatching also attract visitors to destinations throughout the state.

\subsection{Tourism and climate}

Tourism is considered vulnerable to changes in climate, and from a global perspective, climate change will have significant impacts on the tourism system. In the USA, climate change is expected to have a range of regional impacts (USGCRP 2017), some of which will have significant impacts on tourism. Of the 45 climate change plans currently complete 
in the USA, five explicitly address tourism, or both tourism and recreation (Widhalm and Dukes 2020). Although there has been some examination of the impact of climate change on tourism and outdoor recreation across the Great Lakes region (Nicholls 2012; NPCA 2013), this is the first examination of climate change impacts on tourism and recreation in Indiana.

Climate change will impact tourism in various ways (Simpson et al. 2008). Perhaps the most readily identifiable are direct climate impacts and subsequent indirect environmental changes caused by climate change. Weather is a key asset of destinations, and changing climate will benefit some destinations but negatively impact consumer demand for others. Other categories of impact can be considered as well. Mitigation policy impacts, both national and international, may also negatively impact travel and tourism. For example, mitigation strategies such as carbon taxes, which increase travel costs, may reduce demand for travel. Finally, indirect societal change impacts can be considered. This may range from climate change-induced political instability reducing tourism demand (Reinhardt and Toffel 2017; Simpson et al. 2008) to changes in social norms. Some experts speculate that travel may become less socially acceptable as climate change impacts increase (Gössling et al. 2020; Gossling et al. 2011).

Climate has an important influence on the tourism system. It is not surprising that travelers strongly prefer destinations with favorable climates. In recent years, a growing body of research has examined the importance of weather and climate on tourism preferences. Researchers have looked at numerous factors to identify ideal weather conditions. Examining the single variable of temperature (Bigano et al. 2006; Lise and Tol 2002) is the simplest approach, and it is no surprise that an average temperature of $21{ }^{\circ} \mathrm{C}\left(70{ }^{\circ} \mathrm{F}\right)$ as the average temperature of the hottest month of the year is considered optimal (Lise and Tol 2002). Mild weather-defined by moderate temperatures, low precipitation, and low relative humidity - is considered desirable (van der Wiel et al. 2017). Composite indexes that take into account various weather-related factors, such as the Tourism Climatic Index (Mieczkowski 1985), have been applied to tourism and outdoor recreation activities (Ma et al. 2020; Nicholls 2012; Scott et al. 2016b).

In considering if weather is favorable, an important factor is its deviation from expectations (Day et al. 2013). Unseasonably warm or cool temperatures can lead to dissatisfaction with the destination. Although unusual weather may have little impact on tourism demand in the short term (Day et al. 2013), changing perception over time may be significant. Nevertheless, researchers confirm that weather impacts participation in a recreation activity, such as golf (Nicholls et al. 2008).

\subsubsection{Direct impacts of climate change on Indiana's tourism and recreation system}

This assessment of climate change impacts is based on ten statistically downscaled global climate model (GCM) simulations produced for the Indiana Climate Change Impacts Assessment (Hamlet et al. 2019). These simulations predict climate change under two scenarios of greenhouse gas concentrations (a medium scenario, RCP4.5, and a high scenario, RCP8.5) for three future periods, 2011-2040 referred to in the paper as the 2020s, 2041-2071 referred to in the paper as the 2050s, and 2071-2100 referred to in the paper as the 2080s). These simulations have identified numerous changes that will be salient to the Indiana tourism industry and recreation in the state.

Over the past century, Indiana has become warmer by slightly more than $1^{\circ} \mathrm{F}$, has experienced more frequent flooding, and has seen ice on Lake Michigan form later and melt 
earlier (EPA 2016). These trends are expected to accelerate throughout the twenty-first century. Temperatures are projected to rise about 5 to $6^{\circ} \mathrm{F}$ by mid-century, compared to the state's average temperatures from 1971 to 2000, with significantly more warming by the century's end (Hamlet et al. 2019). A rising average temperature increases the chance of extreme heat and reduces the chance of extreme cold. These changes can be summarized as Indiana becoming hotter, wetter, and more likely to experience extreme weather, including storms, floods, and hot days. These shifts will impact participants' comfort in many outdoor activities and may change visitor behavior.

\subsection{Changing seasons}

In the coming century, temperatures are expected to warm in all seasons. The weather we currently associate with spring and summer will start earlier and end later in the year. Winters will also be warmer, according to projections. Of particular importance to tourism and recreation, the number of hot $\left(85-95^{\circ} \mathrm{F}\right.$ ) or extremely hot days (over $95^{\circ} \mathrm{F}$ ) will increase as illustrated in Fig. 1, and the number of mild days $\left(65-85^{\circ} \mathrm{F}\right)$ will decrease, as will the number of cold days. These trends are illustrated in Fig. 2.

These heat levels raise the likelihood of heat-related illnesses, such as heat exhaustion and heat stroke, and they reduce the appeal of some outdoor activities. Children and older adults are especially vulnerable (Filippelli et al. 2020). Some outdoor recreation activities—including sports tourism—-may be impacted by these changes.
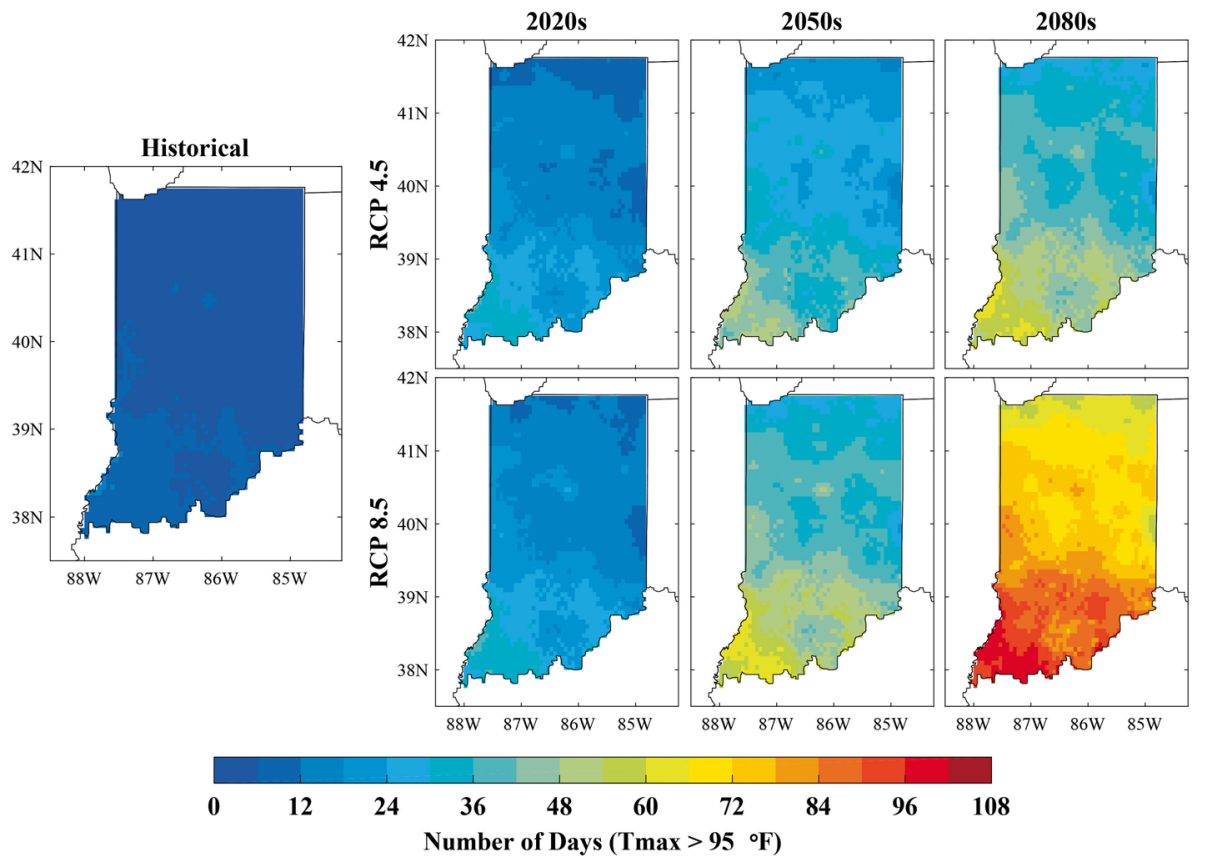

Fig. 1 Extremely hot days in Indiana. Annual number of days with extremely hot temperatures (daily high temperature over $95^{\circ} \mathrm{F}$ ). Seven panels: historical (1915-2013) and 2020s, 2050s, and 2080s with RCP4.5 (medium emissions) and RCP8.5 (high emissions). Graphic originally appears in Hamlet et al. (2019) 


\section{Hoosiers Heating Up}

\section{Number of mild, hot, and extremely hot days in Indiana}

Mild $\left(>65^{\circ} \mathrm{F}\right.$ and $\left.\leq 85^{\circ} \mathrm{F}\right)$
Hot $\left(>85^{\circ} \mathrm{F}\right.$ and $\left.\leq 95^{\circ} \mathrm{F}\right)$
Extreme $\left(>95^{\circ} \mathrm{F}\right)$
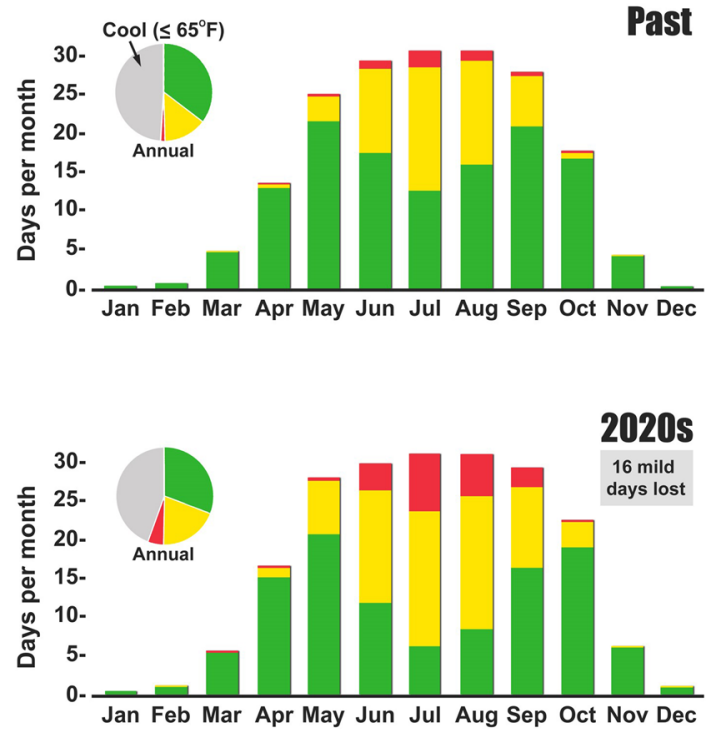

Mild days decline, shoulder seasons shifts - comfortable days from May to Sept are replaced with hot and extremely hot days. Months with predominantly mild weather will start earlier and end later in the year.

\section{Summer heat on the rise, lasting} longer - extremely hot days dominate summer months by end of century. Hot weather days in spring and fall increase.

"Past" is an average for the period 1915 to 2013 . "2020s" represents the average 30-year future period 2011 to 2040. "2050s" represents the average 30 -year period 2041 to 2070 . "2080s" represents the 30 -year period 2071 to 2100 . Future projections are based on average results from 10 climate models based on a high-emissions scenario (Hamlet et al., in press).
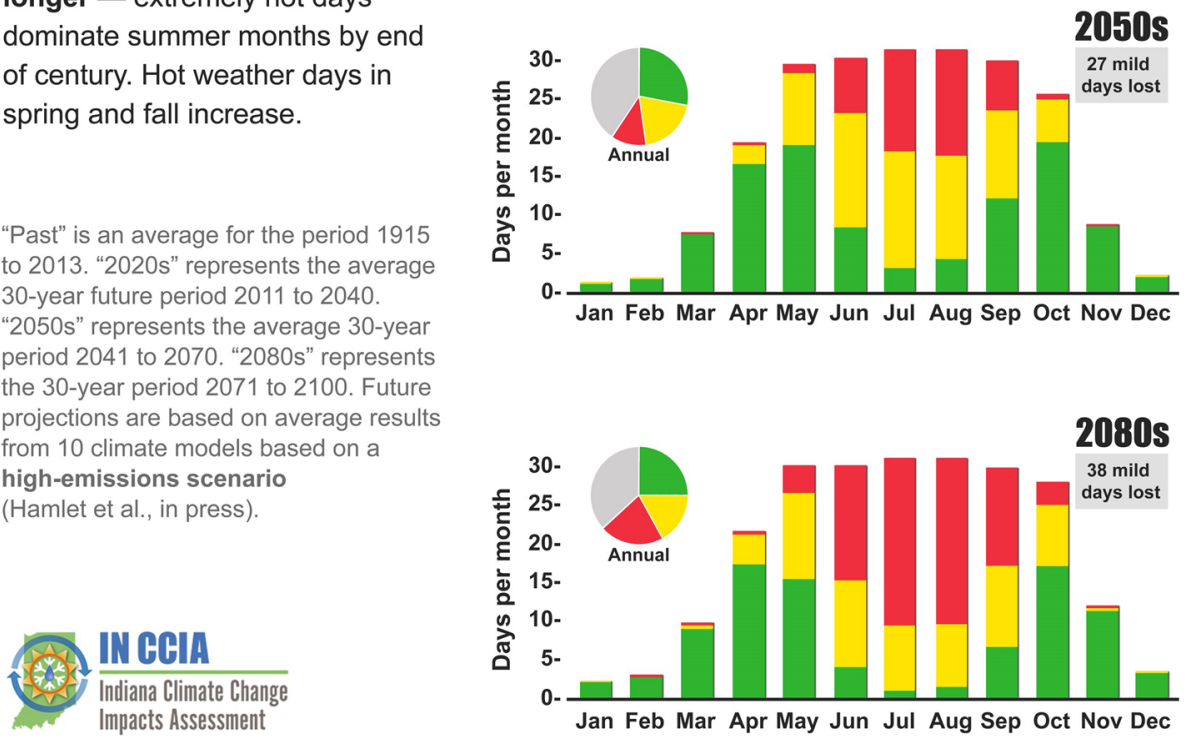

Fig. 2 Hoosiers (Indiana Residents) heating up. Projected number of mild, hot, and extremely hot days in Indiana by month (stacked bars) and annually (pie chart) for the historical period (1915 to 2013) and three future periods based on a high-emissions scenario. For the future projections, "2020s" represents the average from 2011 to 2041, "2050s" represents the average from 2041 to 2070, and "2080s" represents the average from 2071 to 2100

The 2018 Indianapolis (Indy) 500 provides an example of how high temperatures impact events. The Indy 500, the world's oldest automobile race, is described as "the greatest spectacle in racing" (IMS 2019) and is estimated to contribute \$400 million to the Indiana 
economy (500Festival 2019). High temperatures in Indianapolis during the last week of May 2018, when the Indy 500 took place, on average, reached about $76^{\circ} \mathrm{F}$. However, longterm observations show that over the past 60 years temperatures have increased and are currently $3.5^{\circ} \mathrm{F}$ warmer than in 1950. In 2018, high temperatures from May 25 to 31 measured $12{ }^{\circ} \mathrm{F}$ above average. The high temperature on race day was $91{ }^{\circ} \mathrm{F}$, making it the second hottest Indy 500 on record, just shy of the $92{ }^{\circ} \mathrm{F}$ record set in 1937. Hot temperatures and high humidity have an impact on spectators, drivers, and cars at the Indy 500. According to local reports, more than 200 racegoers were treated on-site and/or at the hospital for heat-related illnesses including dehydration, exhaustion, chest pains, and respiratory failure (Tuohy et al. 2018). The weather also impacts the cars in numerous ways that have implications for event organizers. The high temperatures reduce the downforce on cars, making the road feel more slippery. The temperatures also reduce engine efficiency (Sosnowski 2012).

Analysis also shows that humidity has been increasing over time, which could further affect tourists' comfort when participating in outdoor recreation. The Wet Bulb Index, which takes into account both temperature and humidity, projects that by mid-century, Indiana will experience wet bulbtemperatures of $80-86^{\circ} \mathrm{F}$ for $10-30$ days, up from only 1-10 days/year between 1981 and 2010. These conditions are similar to the hottest summer months in humid parts of Texas and Louisiana (Hsiang et al. 2014). Projections suggest that Indiana will even experience wet bulb temperatures above $86^{\circ} \mathrm{F}$ as the century progresses (Hsiang et al. 2014). "Uncomfortable nights," in which hot and humid days are followed by hot and humid nights, will place vulnerable groups, including children and young people, at risk (Filippelli et al. 2020) and increase energy consumption for cooling. Heat and humidity will not only impact visitors' ability to enjoy outdoor activities, but also create challenges for tourism and hospitality workers. As noted in the INCCIA Agriculture Report:

Historically, Indiana's labor capacity - the percentage of hours available for outdoor work in a 24-hour period-has been about 99 percent on average, meaning extreme heat rarely affects our work force. By mid-century, as global temperatures increase by 3 to $4.5^{\circ} \mathrm{F}$, Indiana's labor capacity is projected to decline to about 95 percent for both the high- and medium-emissions scenarios. Labor capacity will continue to decline by late century as global temperatures rise, with a projected average labor capacity of 89 to 95 percent based on high- and medium-emissions scenarios, respectively. (Bowling et al. 2018)

As temperatures rise, Indiana will experience less mild weather, the ideal temperature range for tourism and recreation (van der Wiel et al. 2017). Mild weather is defined as temperatures between 65 and $86{ }^{\circ} \mathrm{F}\left(18\right.$ and $\left.30{ }^{\circ} \mathrm{C}\right)$. As noted in Fig. 2, the remaining mild days will be earlier and later in the year, with hotter periods in the middle of summer. Visitor patterns are expected to change as consumers change behavior based on the best temperatures to undertake outdoor activities, and participation in recreation activities is anticipated to change. This may provide opportunity for some tourism and recreation products, as these changes may increase business beyond the traditional peak seasons. Alternatively, consumers unable to change travel schedules, such as families restricted in their travel with summer vacation periods, may seek alternative destinations to spend their leisure time.

Indiana is a large state with various geographic zones. Although it is possible to identify climate changes that will have impacts across Indiana, it is also necessary to identify future impacts specific to regions. For example, in northern Indiana, near Lake Michigan, many of the changes identified are less pronounced than in southern Indiana. Nevertheless, other impacts will affect the northern part of the state and may impact tourism. For example, 
surface water temperatures on the Great Lakes are expected to increase by $35-54{ }^{\circ} \mathrm{F}$ $\left(2-12{ }^{\circ} \mathrm{C}\right)$ (Kling et al. 2003), and stratification of temperatures in the lake will also change (Höök et al. 2019); these changes will impact fishing populations and fishing tourism (Chin et al. 2019b). Changes in wave action caused by climate change are also expected to impact beaches in the region, and lake water levels are expected to lower, affecting lakeside infrastructure. Southern Indiana is expected to experience higher temperature increases and more significant changes in precipitation (Hamlet et al. 2019).

\subsection{Changing precipitation}

Indiana's average annual precipitation has increased 5.6 inches, or approximately $15 \%$, since 1895, and more rain is falling in heavy downpours. Indiana is projected to see a 6-8\% increase in annual precipitation from the average of the 1971-2000 period, by mid-century, but these changes will not be spread evenly throughout the year. Winters and springs will likely be wetter by mid-century (Hamlet et al. 2019), while expected changes in summer and fall precipitation will be less dramatic. Indeed, as the century progresses and summers become warmer, projections suggest precipitation will decrease in summers by up to $8 \%$ by the 2080s according to some projections (Hamlet et al. 2019). Increased precipitation, especially in the form of heavy rain events, will increase flooding risks. These changes will have a range of impacts for tourism and recreation. Tourism businesses should prepare for extreme weather-related events such as flooding and drought (Hamlet et al. 2019) by building financial reserves and seeking out government assistance programs that support small businesses to increase their resilience.

Indiana is expected to see more rain and less snow during winters in the coming years. The coldest day of the year is expected to warm by about $6{ }^{\circ} \mathrm{F}$, and snow days are expected to decrease by up to 5 days in Northern Indiana (Widhalm et al. 2018). As the century progresses, snowy Christmases will become rarer. Indeed, Southern Indiana may experience no natural snow around the holidays (December 22-January 2) by the end of the century (Chin 2015; Chin et al. 2018).

The impacts of warmer temperatures and reduced snowfall will significantly impact recreational activities. Activities such as ice fishing, cross-country skiing, snowmobiling, and other activities will be affected. Indiana has two commercial ski fields, and based on evidence from other ski locations, the changing climate will likely lead to a greater reliance on artificial snow, shorter seasons, and other operational impacts (Rutty et al. 2017; Steiger et al. 2019). Even so, the number of days with temperatures suitable for artificial snowmaking (defined as days where the maximum temperature is less than $28{ }^{\circ} \mathrm{F}$ ) is expected to decline from 18 days historically to 9 or 10 days by mid-century and as few as 5 days by late century (Chin et al., 2018), further raising the vulnerability of these operations.

\subsection{More extreme weather events}

Historical analysis shows that extreme weather events have been increasing over time and are expected to continue in the coming years (Widhalm et al. 2018). Based on overall increases in temperature, extreme weather events are expected to continue increasing in intensity and frequency in the future (Kossin et al. 2017; Widhalm et al. 2018). These extreme events will include heavy precipitation events and flooding, heat waves, droughts and extreme temperatures, and an increased likelihood of storms. Each of these extreme events has the potential to impact recreation, from delaying sporting events to the 
catastrophic damage caused by the storm-induced stage collapse during a concert at the Indianapolis Fairground in 2011 (Tuohy 2012). Although many impacts of climate change take place gradually over long periods of time and can be managed with minor adaptations, shorter-term shocks will most likely impact business continuity. Evidence shows that acute weather-related issues, such as flooding, disproportionately negatively impact tourism- and hospitality-related businesses. These businesses are often in more vulnerable locations and reliant on visitor demand that decreases following such exogenous events (Sydnor-Bousso et al. 2011). Companies must develop plans and strategies to address these risks and build resilience.

\section{Indirect impacts of climate change}

Climate change will have consequences across the state and impact not only ecological systems, but also socio-cultural systems. Tourism and recreation are embedded in the fabric of life in Indiana, and both will be impacted indirectly as natural and human systems adapt to climate change.

As a result, other impacts identified in the Indiana Climate Change Impact Assessment (INCCIA) will affect tourism. Although each element of the INCCIA report is distinct, it is critical to recognize how the various impacts are interrelated. Each impact has potential indirect impacts on tourism and outdoor recreation. Although the topics addressed in the INCCIA are not comprehensive, they cover a range of issues and provide useful insights into the indirect impacts. The range of impacts is presented in Fig. 3.

Fig. 3 Climate change impacts on tourism and recreation will be impacted by a range of direct and indirect climate-related issues

\section{Findings from all IN EEIA reports have implications for Indiana Tourism and Recreation}

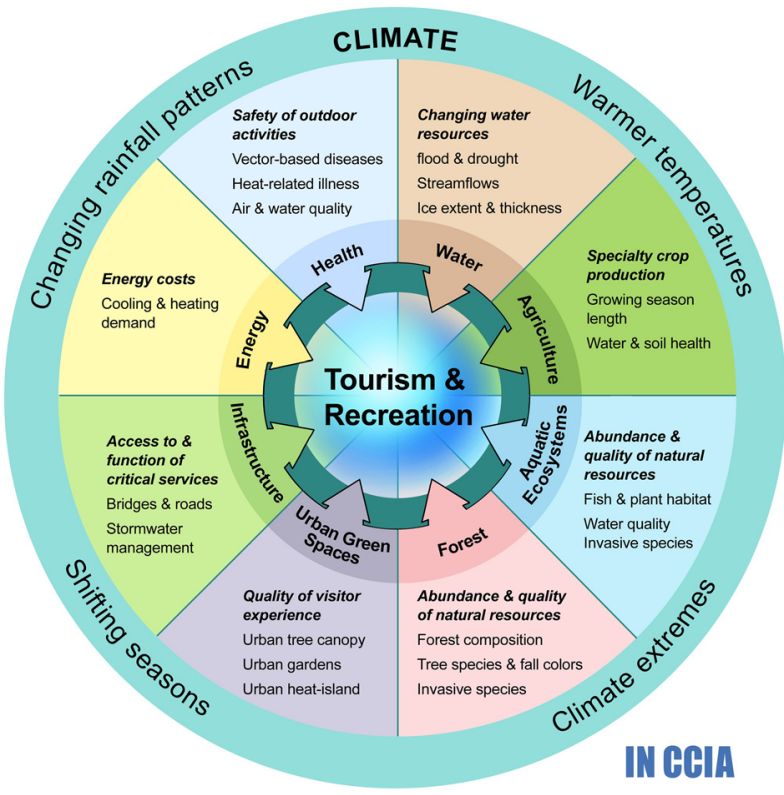




\subsection{Natural systems}

Tourism and recreation are heavily dependent on natural systems, and the impacts of climate change on these systems, from forests to waterways, will impact tourism and recreation. Forests are an important setting for recreation and an important asset for tourism to the state. Indiana's forests are primarily in the southern hills region of the state. Tourists and outdoor recreation enthusiasts enjoy forest ecosystems for hiking, birdwatching, hunting, and other activities. Climate change is expected to impact the composition of Indiana's forests; as a result, changes in wildlife will occur (Phillips et al. 2019). Bird watching is a popular activity in Indiana, and ranges of birds within the state are expected to change as migration patterns for birds popular with birdwatchers change (Phillips et al. 2019). For example, the changing migratory behaviors of the sandhill cranes, many of which stop at the Jasper-Pulaski Fish and Wildlife Area, have been observed (Lacy et al. 2015). Some of these changes may lead to "last chance" tourism as migratory routes change due to climate change. Changes in ecosystems may also affect state hunting destinations as ranges of fauna change. Lakes and rivers are important tourism and recreation assets for Indiana. Lakes and aquatic ecosystems are impacted by temperature and precipitation, and numerous other factors, including thermal conditions, ice cover, water clarity, and oxygen content. These factors have significant direct and indirect impacts on aquatic organisms. In the summer, lakes will be vulnerable to drought as summer temperatures increase and precipitation changes. In the winter, increases in temperatures will reduce ice coverage and limit ice fishing (Höök et al. 2019). Climate change will affect the range and availability of some popular types of native fish. Climate change may also favor invasive species (Höök et al. 2019).

Agritourism has become an essential component of Indiana's tourism portfolio. Agritourism in the state takes numerous forms, many of which will be impacted by climate change. Agriculture most associated with agritourism in the state includes fruit producers and vineyards. These crops-including apples, peaches, and grape varieties-will be impacted by changing chilling patterns and increasing temperatures. Current varieties may experience reducing yields, and some varieties may be replaced (Bowling et al. 2020).

Two tree crops that attract visitors-maple and Christmas trees-are expected to be impacted by the changing climate. On average, Indiana produces 10,000 gallons of maple syrup per year, which is influenced by weather (Phillips et al. 2018). Climate change is expected to impact syrup production, reducing the length of time that syrup is produced, thus impacting the appeal of agritourism attractions featuring syrup production. The maple syrup season is a time when several destinations in the state hold festivals and events to attract visitors. Similarly, Christmas trees attract many visitors to Indiana with "choose and cut" farms that provide a traditional family experience each year. The production of these trees may also be impacted by warmer summers (Phillips et al. 2018), which will subsequently impact these agritourism experiences.

Wineries have become an important part of Indiana's agritourism offerings and an appealing attraction for many visitors. As the climate changes, grape growth is expected to change (Mozell and Thach 2014). Climate change is already impacting the types of grapes grown in Indiana, with some southern Indiana vineyards experimenting with Vitis vinifera varieties, rather than the hardier hybrids traditionally grown in the state (van Hoose 2016).

Fall foliage is an important attraction for southern Indiana, drawing visitors and tourists in large numbers. Preliminary analysis suggests that changes in 
weather-particularly rainfall, temperature, and sunlight-and ecosystems will impact the fall foliage experience (Xie 2016). Not only will it be more challenging to predict fall foliage dates due to the interplay of climate and ecosystem change, but extreme events such as storms will be more common, leading to higher chances that the season will end prematurely (Climate Central 2016; Thompson 2016). Research on the impact of climate change and resulting forest composition impacts on fall foliage has not been undertaken to date, yet the implications for tourism will likely be significant.

\subsection{Social systems and infrastructure}

In addition to natural systems, climate change will impact social systems and infrastructure. Water management, energy production, health, and health services will all be affected by either direct or indirect climate change impacts. Management of water resources will become increasingly important as water systems evolve in the face of a changing climate. Indiana will need to prepare to store water in hotter, high-demand periods, which typically coincide with higher water demands from tourists and visitors. Indiana communities will also need to prepare for the increased likelihood of flooding. Additionally, communities will deal with increased sewer discharges from overflows in wastewater management systems (Cherkauer et al. 2021). Climate change is expected to have a modest impact on energy demand in Indiana. Although Indiana's energy demand for cooling during the summer months is expected to increase, winter heating will decrease (Raymond et al. 2019). Indeed, Indiana's northernmost cities are expected to show significant increases in energy demand-particularly cooling (Singh and Wachs 2020). Raymond et al. (2019) note that commercial energy users will see a 5-5.5\% increase in energy demand for cooling based on projections through the 2080s. Tourism and recreation businesses must anticipate increased energy demand for cooling during the warmer summer months.

Filippelli et al. (2020) highlight numerous health-related issues associated with the changing climate. These health-related issues include increasing heat-related injuries and deaths, respiratory problems associated with increased ozone and allergens in the air, and changing disease profiles as the range of ticks increases and mosquito-related diseases evolve and increase. These changes will impact tourism and recreation behaviors, from the level of activity during certain times of year to the appeal of specific activities and locations. They will also impact the tourism and recreation workforces. We know high temperatures have the capacity to exacerbate some existing health conditions, and recent research suggests that marginalized groups might exhibit increased vulnerability to higher-thannormal temperature days (Basu 2009; Yardley et al. 2011). Some of the work from this stream of research identifies the effects of redlining, where investments in Black neighborhoods were withheld and classified as risky, draining wealth from the areas. Today, these neighborhoods risk greater negative impacts, including higher mortality rates, from climate change (Hoffman et al. 2020). Increases in green urban infrastructure in Indiana could help mitigate these impacts (Filippelli et al. 2020).

\section{Discussion and implications}

The impacts of climate change — both direct and indirect—will affect tourism in many ways. Although some changes are predictable, others are harder to anticipate due to the tourism system's complexity. Tourism is a complex adaptive system (Day 2016; Farrell 
and Twining-Ward 2005; Morrison et al. 2018) that responds to outside influences such as changing markets, new technology, and even climate change. The variety of organizations interacting with each other and individual consumers creates complexity in the tourism system, and climate change's impacts on the system will affect these actors in different ways. Indeed, each actor will respond to the impacts as they see appropriate. These responses may then impact other members of the system, requiring even more change. Generally speaking, responses to climate change are categorized as either adaptation or mitigation. Adaptation can be described as "actions that make an organization more resilient in the face of ongoing and forecast changes in the earth's systems" (Reinhardt and Toffel 2017). Climate change mitigation entails the ways in which actors in the system work to reduce their greenhouse gases (GHGs) and contribute to eliminating, or at least slowing, climate change. The tourism system is undertaking both adaptation and mitigation activities.

\subsection{Adaptation}

The adaptive responses of entities within the tourism system vary widely and can be considered using different levels of analysis. The macro-level analysis considers destination communities, meso-level analysis addresses individual businesses, and micro-level analysis examines individual behaviors, including organizational behavior and individual traveler behavior.

Macro-level policy responses to climate change are lacking at the national and state levels. The USA has rejoined the Paris Climate Agreement and committed to climate action. Although there is optimism about this move, in 2021, the USA still does not have a national climate strategy. Similarly, Indiana does not have a state-level climate change plan. Nevertheless, climate change will require various community-level responses, and Indiana's institutions, including city and county governments, will need to respond. Tourism is dependent on infrastructure, such as roads and highways, energy, and water. Some community-level planning for climate change has begun in Indiana. Two of the first plans, for Indiana Dunes (Moore-Powell et al. 2018) and Bloomington (Redmond et al. 2020), do not include a specific focus on recreation or tourism. Some towns are already responding to climate change issues. For example, the city of Elkhart, Indiana, has developed a riverside trail system as an adaptation to anticipated increases in flooding (YCC-Team 2020). The River Greenway is promoted to bikers, walkers, and birdwatchers (Elkhart Well Crafted County, Indiana: Biking and Walking 2020). Reynolds et al. (2019) advocate for the development of green infrastructure as a means of increasing community resilience to climate change in Indiana. Similarly, Origin Park, a 600-acre park planned for the banks of the Ohio River, will be both resilient to climate change and attract visitors from Indiana and nearby Louisville (Byrne 2020). Although tourism is not the primary driver of demand for these and other community-based services, it should be considered in the planning and development processes for these services.

How companies respond to climate change depends on various factors, including their understanding of the potential impacts. Preliminary studies with tourism operators in northern Indiana indicated that operators pay close attention to weather and are aware of climate changes (Chin et al. 2019b). Nevertheless, for these managers, responding to weather is a daily responsibility, and adaptation tends to be operational. Typical responses include adjusting part-time/seasonal workers' schedules or adjusting facilities to accommodate weather changes such as rain or heat. Impacts of changing weather, including increased heat, will impact workers and visitors, and businesses will need to adjust accordingly. In 
general, these managers see climate change as "slow moving and low risk" (Chin 2015). There has been little concern for committing to major capital outlays in response to climate change, and Indiana is not alone in showing reluctance to invest in climate change adaptation. For instance, a study of Australian tourism operators found that although many were concerned about climate change, few had clear plans for adapting (Turton et al. 2010). Nevertheless, engaging businesses in climate change responses is essential (Chin et al. 2019b; Nicholls and Holecek 2008). Most companies will face changes in business costs. As noted in the report on Indiana's energy demand (Raymond et al. 2019), most businesses in the state can expect some change in energy consumption and costs, with increasing cooling needs in summer and decreasing heating needs in winter. Preliminary evidence suggests that small tourism business operators, including Indiana operators, lack information on financing options and access to funds for adaptation costs (Chin et al. 2018). While operational changes are the first consideration in responding to climate change, other responses are possible. For instance, Tang and Jang (2012) suggest that financial hedging using weather derivatives may significantly reduce cash flow volatility.

Evidence shows that businesses are already adapting to the indirect impacts of climate change. For instance, fishing businesses operating on Lake Michigan have adjusted the types of fish they seek based on changes in the water (Chin 2015). Marinas along the shores of Lake Michigan are also adapting to climate change. A study of marina and harbor operators in neighboring Michigan noted that marinas will be impacted by shorter winters, warmer temperatures, more intense storms, and fluctuating lake levels. The report identified the need for infrastructure upgrades to facilities, such as installing floating docks, improving stormwater management, and implementing shoreline protections, in preparation for climate changes (Samples et al. 2015). Marinas and harbor operations clearly benefit from both specific climate change planning and broader tourism- and community-based strategies.

It is important to recognize that tourism and recreation operators are heterogeneous. Actors in the system differ in their ability to adapt within a given period (Simpson et al. 2008), and they tend to plan and operate within different time frames. Consumers can respond relatively quickly to climate change, changing their travel choices from trip to trip. Many tourism businesses operate on relatively short time horizons, making operational changes in response to weather. Tourism developers and government entities responsible for infrastructure, such as roads, have a longer-term perspective.

Of all the actors in the tourism system, consumers are most able to adapt to climate change (Gossling et al. 2011), as they can easily change travel plans on short notice. Consumers have various options when faced with poor weather and a changing climate. Deferring travel and changing destinations are possibilities, but how climate change will impact markets and travel patterns is uncertain and difficult to predict. Climate change will impact specific activities; for instance, if climate change reduces the likelihood of seeing a particular bird species, as is predicted for Indiana (Höök et al. 2019; Phillips et al. 2019), that demand will likely reduce, both for general tourists and avid birdwatchers. Similar observations have been made with other species around the country (Lambert et al. 2010). The difference in timing of mild weather during the year-earlier in spring and later in fallmay cause the seasonality of many outdoor activities to change. From shopping and antiquing to more vigorous activities, avoiding the high temperatures of summer may increase business in new times of the year.

Two recent studies of US travelers show growing awareness of climate change issues. MMGY global's "Portrait of the America Traveler" shows $48 \%$ of travelers agree that climate change will have a significant influence on what destinations they choose to visit 
in the next 5 years (MMGYGlobal 2019). Destination analysts' "State of the American Traveler" (2019) shows that 50\% of American leisure travelers expect climate change will impact their travels at some point in the next 5 years. Destination analysts' reports that $28.5 \%$ of travelers expect climate change will affect the timing of trips, $20.9 \%$ will change the destinations they choose, and $15.2 \%$ will adjust how they travel. As may be expected, evidence exists that consumers can be segmented, with different markets more concerned than others (McKercher et al. 2010).

Climate change has different implications depending on the spatio-temporal frame through which it is examined. Weather impacts daily operations, and several researchers have examined the impacts on specific weather conditions. Nicholls et al. (2008) noted that weather had a significant impact on demand for golfing facilities and noted these impacts might provide insights into the impacts of long-term demand. Preliminary evidence suggests that perceptions of the climate at a destination may be more important to travel decisions than specific weather events. In the short term, bad weather does not necessarily affect the likelihood to travel (Day et al. 2013; Rutty et al. 2017). However, over time, disappointment in weather conditions may have lasting impacts on destination reputation. Poor weather reduces visitors' satisfaction with the destination experience (Coghlan and Prideaux 2009) and their intention to return. Indiana's tourism and recreation organizations will need to monitor these changes in consumer satisfaction and behavior to adapt to changes in demand effectively.

\subsection{Mitigation}

The tourism industry, much like other industries, has played a role in the emission of greenhouse gases (GHG). It is estimated that tourism contributes $5 \%$ of total manmade emissions worldwide (Scott et al. 2016a). Of tourism-related $\mathrm{CO}_{2}$ emissions, air travel contributes more than half (52\%), with hotels and other tourism-related buildings contributing 27\% and automobiles 19\% (Hall 2015). Various sectors of the tourism system are currently undertaking mitigation activities. Examples of mitigation strategies can be found in aviation, hotels and lodging, and restaurants and food service. For example, the aviation industry has prioritized reducing emissions (Airlines for America 2018). Hotels and restaurants-particularly major brands-have instituted programs focused on energy and water efficiency that will reduce GHG production. These national programs extend to these organizations' Indiana operations. National industry associations, such as Destination International, the American Hotel and Lodging Association, and the National Restaurant Association, have adopted programs to promote environmental sustainability, although Indiana's local tourism and hospitality industry associations have been slower to address these issues.

Travelers have an important role in reducing climate change. Individual behavior has the potential to reduce GHG emissions. While awareness of climate change as an issue for US travelers is increasing (Destination Analysts 2019; MMGY Global 2019), evidence of behavior change has been limited. This may change if the USA follows other markets where "flight shaming" (Baron 2019; Thornhill 2019) discourages air travel, and other social trends are beginning to influence travel demand. Nevertheless, changes in transportation, such as the adoption of hybrid and electric vehicles by traveling consumers, will impact the visitor economy and system changes, including the provision of new electric vehicle-charging infrastructure that will be required (Gorner et al. 2019). Indiana has recognized these needs and received funding from the Volkswagen Environmental Mitigation 
Trust for a "Crossroads of America Electric Vehicle Corridor" with the goal of ensuring strategic positioning of electric charging stations on major Indiana highways (IEA 2020).

\section{Key knowledge gaps}

Although knowledge of how climate change will impact Indiana is increasing, this case study identifies significant gaps in our understanding of the impacts on tourism and recreation. While climate science is increasingly precise, research is needed on the indirect socioeconomic and socio-environmental effects of projected changes and their implications for tourism. Understanding the impacts of climate change on tourism and recreation requires a multidisciplinary approach that incorporates fields as diverse as political science, sociology, economics, behavioral science, and climate science. Given the human dimensions of these issues, both qualitative and quantitative analyses will be required to address the gaps in our understanding.

\subsection{Levels of analysis}

The study of climate change impacts requires an understanding of climate and social and behavioral responses. Climate change has societal impacts, and research must be undertaken at each level of analysis. These analysis levels include the destination community (macro-level), business and enterprise (meso level), and individual behavior (micro-level). Further, more research is needed to understand the interrelationships between these levels within the tourism system. The impacts of climate change, particularly indirect impacts, are often nonlinear, and understanding the relationships between various system elements is critical.

At the macro-level, policy decisions affecting infrastructure, decisions about the energy mix within the state, and even the impact of climate change on other industries, such as agriculture, will affect tourism and recreation. Research is needed on the relationship between climate-related policy at national, state, and local levels and tourism. Like the Indiana Dunes (Moore-Powell et al. 2018), some Indiana communities have begun climate change adaptation planning, but few explicitly incorporate tourism plans in their studies. Little research has been undertaken on the effective development of policy and destination planning for climate change to incorporate the needs of recreation and tourism.

Enterprise-level studies on the impacts of climate change for Indiana remain extremely limited, and additional research is needed to understand how tourism businesses will be affected. We must learn more about how enterprises respond to risk and how building resilience can be encouraged. Evidence suggests that Indiana tourism businesses are already dealing with climate change, but there is a paucity of information on preparing for future change (Chin et al. 2019b). Specific research areas may include studies to understand the barriers to and drivers of climate change adaptation and mitigation activities. Indeed, understanding practical issues facing tourism and recreational businesses, such as availability and utilization of appropriate insurance and government incentives as well as availability of energy-efficient technologies, is required. Further understanding of the transfer of technology, techniques, and knowledge within the tourism industry is necessary to support ongoing change efforts. Further research is also critical to understanding the impacts of organizational behavior and climate change. For example, understanding the information needs of key stakeholders to respond to change remains limited and requires additional 
research. While some researchers, including Ayscue et al. (2015) and (Day et al. 2013), examined weather-related information needs, the general consensus is that knowledge management is lacking (Loehr and Becken 2021). Chin et al. (2019a) note that Indiana managers of tourism organizations have limited knowledge of climate change impacts. Further, as knowledge does not necessarily lead to action, a greater understanding of adaptive and resilience-oriented action motivators is also required. Responses to climate change from managers and leaders within organizations remain poorly understood and require additional research.

\subsection{Heterogeneity of tourism and recreation}

Tourism and recreation represent a broad range of heterogeneous activities and organizations. Understanding the impacts of climate change on each sector within the tourism system is critical. Similarly, even within Indiana, each destination community faces unique challenges. Understanding the specific vulnerabilities of communities and businesses requires further analysis. Further, significant gaps exist in our understanding of the indirect impacts of climate change and its impacts on tourism and recreation entities.

\subsection{Significance of impacts}

We also lack knowledge of the significance of anticipated changes to tourism and recreation activity. In terms of direct impacts, research is required to determine the limits of acceptable change for consumers as the climate within Indiana changes and to understand what thresholds will lead to changes in behavior. This research requires a complex tapestry of studies, as it is reasonable to expect each activity - from football practice to hiking in a state park-will have its own profile. Further, the changes in climate beyond the state borders will influence behavior in Indiana.

We have identified several indirect impacts of climate change that may impact tourism and recreation, but we have little understanding of the significance of these changes. For example, while a possible reduction in sandhill cranes may impact birdwatching at the Jasper Pulaski Fish and Wildlife Area, it is unclear whether changes in birdlife composition in a forest will impact visitation to the recreation area in which the forest is located. Early evidence from tourism-oriented fishing operations suggests that one type of fish may be substituted for another without reducing the overall demand for fishing services (Chin et al. $2019 b)$. So while it is reasonable to note that there will be impacts, the level and significance of the impact may vary by activity. Further research on the elasticity of these relationships is needed.

\subsection{Impacts through time and space}

Recognition of the temporal dimensions of climate change impacts has been limited. Several researchers have examined the relationship between weather and tourism or recreation activities as a proxy for climate change (Day et al. 2013; Nicholls et al. 2008). Although these analyses may provide some insight, they fail to recognize many factors that will impact long-term behaviors. Similarly, most climate change research currently focuses on how specific locations will be impacted without considering changes that will occur in other locations. Changing demand factors will be influenced by changes in 
climate in the focal destination and changes in other destinations. For example, despite rising temperatures in Indiana, the state may become more appealing to visitors as Southern states become even more hot and humid. Indiana's tourism will be influenced by its own responses to climate change and other destination responses across the country. Although climate indices, including the tourism climatic index (Amelung et al. 2007; Mieczkowski 1985), campaign climate index (Ma et al. 2020), or the holiday climate index (Scott et al. 2016b) may provide insights into the direct impact of weather on visitors flows, they are less useful for anticipating the indirect impacts of climate change on the tourism system.

\section{Conclusion and implications}

This case study applies a socio-environmental systems lens to the climate change impacts on tourism and recreation in Indiana. The study also provides important insights into the challenges facing destinations while highlighting the gaps in our understanding of the impacts of climate change on tourism. The case highlights that, despite increasing certainty about specific changes in climate, the complex nature of system responses demands more research. The study has expanded the discussion of climate change impacts to consider societal analysis levels, the significance of anticipated changes, and the importance of temporal and spatial frames in considering impacts.

Climate change in Indiana will have direct and indirect impacts on tourism and recreation, and many actors throughout the tourism system will need to respond. Organizations not traditionally considered tourism organizations, such as energy utilities and other government entities, play important roles in the tourism system. Systems, like the tourism system, are characterized by nonlinear responses, and changes in one part of the system may have unanticipated impacts on other parts of the system. Travelers and visitors can easily alter behavior in ways that will significantly affect conventional business patterns. Businesses will face new costs and increased risks, and they must be prepared to respond. Communities must consider tourists' and visitors' needs in planning for infrastructure and services. Paradoxically, despite the existential challenge of climate change, predictable changes will take place slowly over the long term for many tourism and recreation providers and require relatively minor adaptation.

As a result, tourism stakeholders in Indiana must seek to understand the changes taking place, respond as appropriate, and learn from the challenges. The awareness of change, both predicted and unexpected, allows for response and ensures resilience in a state impacted by climate change.

Acknowledgements This paper is a contribution to the Indiana Climate Change Impacts Assessment (INCCIA). The INCCIA is organized and financially supported by the Purdue Climate Change Research Center.

Funding The INCCIA is organized and financially supported by the Purdue Climate Change Research Center.

Purdue Climate Change Research Center,Purdue University

Data availability Not applicable.

\section{Declarations}

Ethics approval Not applicable. 
Conflict of interest/Competing interests.

The authors declare no competing interests.

\section{References}

500Festival (2019) Economic impact: positively influencing the community. https://www.500festival.com/ about-us/economic-impact/. Accessed 2/11/2021

Airlines for America (2018) Airlines for America I policy priorities I Learn More. Airlines for America. http://airlines.org/policy-priorities-learn-more/\#energy. Accessed 2/11/2021

Amelung B, Nicholls S, Viner D (2007) Implications of global climate change for tourism flows and seasonality J Travel Res 45

Ayscue EP, Curtis S, Hao H, Montz B (2015) Forecast and weather-related information used among coastal tourism businesses. Tour Geogr 17:603-626. https://doi.org/10.1080/14616688.2015.1053974

Baron J (2019) Flight-shaming is now a thing - will it keep you from traveling? Forbes. https://www.forbes. com/sites/jessicabaron/2019/07/02/flight-shaming-is-now-a-thing--will-it-keep-you-from-traveling/\# 3a255a5671a3. Accessed 2/11/2021

Basu R (2009) High ambient temperature and mortality: a review of epidemiologic studies from 2001 to 2008 Environ Health 8:40-40 https://doi.org/10.1186/1476-069x-8-40

Bigano A, Hamilton J, Tol R (2006) The Impact of Climate on Holiday Choice Climatic Change 76:389-406

Bowling L et al (2018) Indiana's agriculture in a changing climate: a report from the Indiana climate change impacts assessment. Purdue University, West Lafayette, Indiana

Bowling LC et al (2020) Agricultural impacts of climate change in Indiana and potential adaptations. Clim Change 163:2005-2027. https://doi.org/10.1007/s10584-020-02934-9

Byrne S (2020) Riverfront park designed to "lean in"” to climate change. The Waterways Journal, St Louis, Mo

Cherkauer KA et al (2021) Climate change impacts and strategies for adaptation for water resource management in Indiana. Clim Change 165:21. https://doi.org/10.1007/s10584-021-02979-4

Chin N, Day J, Sydnor S, Prokopy LS, Cherkauer KA (2019b). Exploring Tourism Businesses' Adaptive Response to Climate Change in Two Great Lakes Destination Communities Journal of Destination Marketing \& Management. https://doi.org/10.1016/j.jdmm.2018.12.009

Chin N, Byun K, Hamlet A, Cherkauer K (2018) Assessing potential winter weather response to climate change and implications for tourism in the U.S. Great Lakes and Midwest Journal of Hydrology: Regional Studies In Press

Chin N, Day J, Sydnor S (2019a) The climate change paradox: small to medium tourism enterprise and climate change on the great lakes. Paper presented at the TTRA 2019 International Conference, Melbourne, Australia,

Chin N (2015) Dissertation exploring the potential impacts of climate change on North America's Laurentian Great Lakes tourism sector. Dissertation, Purdue University

ClimateCentral (2016) Climate change and fall foliage. ClimateCentral.org. http://www.climatecentral.org/ gallery/graphics/climate-change-and-fall-foliage. Accessed 2/11/2021

Coghlan A, Prideaux B (2009) Welcome to the Wet Tropics: the Importance of Weather in Reef Tourism Resilience Current Issues in Tourism 12:89-104

Davos Declaration: climate change and tourism responding to global challenges. In: Second International Conference on Climate Change and Tourism, Davos, Switzerland, 2007. UNWTO, UNEP, WMO, WEF,

Day J, Chin N, Sydnor S, Cherkauer K (2013) Weather, Climate and Tourism Performance: A Quantitative Analysis Tourism Management. Perspectives 5:51-56. https://doi.org/10.1016/j.tmp.2012.11.001

Day J (2016) An introduction to sustainable tourism and responsible travel. Beta edn. Placemark Solutions, West Lafayette, IN

Destination Analysts (2019) State of the American traveler: destination edition vol 31 - Winter 2019.

Elkhart Well Crafted County, Indiana: biking and walking. (2020) Elkhart County Convention and Visitors Bureau. Accessed 091720202020

EPA (2016) What climate change means for Indiana. EPA United States Environmental Protection Agency. https://19january2017snapshot.epa.gov/sites/production/files/2016-09/documents/climate-change-in. pdf. Accessed 12/11/2021

Farrell B, Twining-Ward L (2005) Seven steps towards sustainability: tourism in the context of new knowledge. J Sustain Tour 13:109-122 
Filippelli G et al. (2020) Climate change impacts on human health at an actionable scale: a state-level assessment of Indiana, USA. Climatic Change

Garulski J (2007) Indianal2006 visitor profile (Public Version). D.K.Shifflet \& Associates, Indianapolis

Gorner M, Scheffer S, Cazzola P (2019) Electric vehicles: tracking clean energy progress. International Energy Agency. https://www.iea.org/tcep/transport/electricvehicles/. Accessed 2/11/2021

Gossling S, Scott D, Hall M, Ceron J, Dubois G (2011) Consumer behavior and demand response of tourists to climate change. Ann Tour Res 39:36-58

Gössling S, Humpe A, Bausch T (2020) Does 'flight shame' affect social norms? Changing Perspectives on the Desirability of Air Travel in Germany Journal of Cleaner Production 266:122015. https://doi.org/ 10.1016/j.jclepro.2020.122015

Hall C (2015) Can tourism tackle climate change? World Economic Forum. https://www.weforum.org/ agenda/2015/12/can-tourism-tackle-climate-change/. Accessed 2/11/2021

Hamlet A, Byun K, Robeson S, Widhalm M, Baldwin M (2019) Impacts of climate change on the state of Indiana: ensemble future projections based on statistical downscaling. Clim Change. https://doi.org/10. 1007/s10584-018-2309-9

Hoffman JS, Shandas V, Pendleton N (2020) The effects of historical housing policies on resident exposure to intra-urban heat: a study of 108 US urban areas climate $8: 12$

Höök TO et al (2019) An assessment of the potential impacts of climate change on freshwater habitats and biota of Indiana. USA Climatic Change. https://doi.org/10.1007/s10584-019-02502-w

Hsiang S et al. (2014) American climate prospectus: economic risks in the United States, 1.2 edn. Rhodium Group, New York

IEA (2020) Indiana Energy Association: electric vehicles. Indiana Energy Association. https://indianaene rgy.org/electric-vehicles/. Accessed 190920202020

IMS (2019) Indy 500. Indianapolis Motor Speedway. https://www.indianapolismotorspeedway.com/events/ indy500. 2019

IOTD (2020a) Another record year for Indiana tourism. Indiana Office of Tourism Development. https:// www.visitindianatourism.com/sites/default/files/documents/2019-data-economic-impact-infographics. pdf. 2020

IOTD (2020b) Indiana destination development corporation established, board appointed. Indiana Office of Tourism Development. https://www.visitindianatourism.com/node/449. 2020

ISFA (2018) Indiana festivals: about us. Indiana State Festivals Association. http://www.indianafestivals. org/about/.

Kling GW et al (2003) Confronting climate change in the Great Lakes region: impacts on our communities and ecosystems. Ecological Society of America, Union of Concerned Scientists

Kossin J, Hall T, Knutsen K, Trapp R, Waliser D, Wehner M (2017) Extreme storms. In: Wuebbles D, Fahey K, Hibbard D, Dokken B, Stewart B, Maycock T (eds) Climate Science Special Report: Fourth National Climate Assessment, vol 1. Washington DC, pp 257-276. https://doi.org/10.7930/J07S7KXX

Lacy AE, Barzen JA, Moore DM, Norris KE (2015) Changes in the Number and Distribution of Greater Sandhill Cranes in the Eastern Population Journal of Field Ornithology 86:317-325. https://doi.org/10. 1111 jofo. 12124

Lambert E, Hunter C, Pierce GJ, Macleod CD (2010) Sustainable whale-watching tourism and climate change: towards a framework of resilience. J Sustain Tour 18:409-427. https://doi.org/10.1080/09669 581003655497

Lise W, Tol R (2002) Impact of Climate on Tourist Demand Climatic Change 55:429-449

Loehr J, Becken S (2021) The tourism climate change knowledge system Annals of tourism research 86 doi:https://doi.org/10.1016/j.annals.2020.103073

Ma S, Craig CA, Feng S (2020) The camping climate index (CCI): the development, validation, and application of a camping-sector tourism climate index Tourism Management 80:N.PAG-N.PAG. https://doi. org/10.1016/j.tourman.2020.104105

McKercher B, Prideaux B, Cheung C, Law R (2010) Achieving voluntary reductions in the carbon footprint of tourism and climate change. J Sustain Tour 18:297-317

Mieczkowski Z (1985) The tourism climatic index: a method for evaluating world climates for tourism. Can Geogr 29:220-233

MMGYGlobal (2019) MMGY GLOBAL'S portrait of American travelers survey reveals significant shifts in what is influencing travelers most. MMGY Global. https://www.mmgyglobal.com/news/mmgy-globa 1s-portrait-of-american-travelers-survey-reveals-significant-shifts-in-what-is-influencing-travelersmost/. Accessed 8/24/2019 2019

Moore-Powell K, Lewis A, Stotz D (2018) Indiana dunes climate change adaptation plan. Indiana Lake Michigan Coastal Program, Save the Dunes, Field Museum, NOAA,

Morrison A, Lehto X, Day J (2018) The tourism system. 8th edn. Kendall Hunt, Dubuque, Iowa 
Mozell MR, Thach L (2014) The Impact of Climate Change on the Global Wine Industry: Challenges \& Solutions Wine Economics and Policy 3:81-89. https://doi.org/10.1016/j.wep.2014.08.001

Newman M (2017) 2017 Annual report - presentation. Indiana Office of Tourism Devevelopment, Indianapolis, Indiana

Nicholls S, Holecek DF (2008) Engaging tourism stakeholders in the development of climate change decision-support tools: a case study from Michigan. USA Tourism Review International 12:25-42. https://doi.org/10.3727/154427208785899966

Nicholls S, Holecek DF, Noh J (2008) Impact of weather variability on golfing activity and implications of climate change. Tour Anal 13:117-130. https://doi.org/10.3727/108354208785664256

Nicholls S (2012) Outdoor recreation and tourism. In: Winkler J, Andresen J, Hatfield J, Bidwell D, Brown D (eds) U.S. National Climate Assessment Midwest Technical Input Report. National Climate Assessment, Great Lakes Intergrated Sciences and Assessments Center,

NPCA (2013) Climate adaptation: a resource guide for great lakes national parks and communities. National Parks Conservation Association, Washington, DC - National Parks Conservation Association

Phillips R et al (2018) Indiana's future forests: a report from the Indiana climate change impacts assessmsnt. Purdue University, West Lafayette Indiana

Phillips RP et al. (2019) An integrated assessment of the potential impacts of climate change on Indiana forests Climatic Change:<xocs:firstpage xmlns:xocs=""/> https://doi.org/10.1007/s10584-018-2326-8

Raymond L et al. (2019) Projected climate change impacts on Indiana's energy demand and supply Climatic Change:1-15 doi:https://doi.org/10.1007/s10584-018-2299-7

Redmond T, Redmond C, Giorgi V (2020) City of bloomington draft climate action plan city of Bloomington, Bloomington, Indiana

Reinhardt FL, Toffel MW (2017) Managing climate change: lessons from the U.S. navy Harvard Business Review 95:102-111

Reynolds HL et al (2019) Implications of climate change for managing urban green infrastructure: an Indiana. US Case Study Climatic Change. https://doi.org/10.1007/s10584-019-02617-0

RockportAnalytics (2020) Economic impact of tourism in Indiana Rockport Analytics, Annapolis, MD

Rutty M, Scott D, Johnson P, Pons M, Steiger R, Vilella M (2017) Using ski industry response to climatic variability to assess climate change risk: an analogue study in Eastern Canada Tourism. Manage 58:196-204. https://doi.org/10.1016/j.tourman.2016.10.020

Samples A, Rieseng C, Day J (2015) Engaging Marina and Harbor Operators in Climate Action Michigan Journal of Sustainability 3:65-72. https://doi.org/10.3998/mjs.12333712.0003.004

Scott D, Hall CM, Gössling S (2016a) A review of the IPCC Fifth Assessment and implications for tourism sector climate resilience and decarbonization. J Sustain Tour 24:8-30. https://doi.org/10.1080/ 09669582.2015.1062021

Scott D, Rutty M, Amelung B, Tang M (2016b) An inter-comparison of the holiday climate index (HCI) and the tourism climate index (TCI) in Europe. Atmosphere 7:80. https://doi.org/10.3390/atmos7060080

Simpson M, Gossling S, Scott D, Hall C, Gladin E (2008) Climate change adaptation and mitigation in the tourism sector: frameworks, tools and practices. University of Oxford, UNWTO, WMO, Paris, France, UNEP

Singh S, Wachs L (2020) Projecting the urban energy demand for Indiana, USA, in 2050 and 2080 Climatic change. https://doi.org/10.1007/s10584-019-02618-z

Sosnowski A (2012) Record Heat for the Indy 500. Accuweaher. https://www.accuweather.com/en/weath er-news/record-heat-at-the-indy-500/65640. 2018

Steiger R, Scott D, Abegg B, Pons M, Aall C (2019) A Critical Review of Climate Change Risk for Ski Tourism Current Issues in Tourism 22:1343-1379. https://doi.org/10.1080/13683500.2017.1410110

Sydnor-Bousso S, Stafford K, Tews M, Adler H (2011) Towards a Resilience Model for the Hospitality and Tourism Industry Journal of Human Resources in Hospitality and Tourism 10:195-217

Tang C, Jang S (2012) Hedging Weather Related Risk in Nature-Based Tourism Business: an Example of Ski Resorts Journal of Hospitality and Tourism Research 36:143-163

Thompson A (2016) Drought and climate change could throw fall colors off schedule. Scientific American. https://www.scientificamerican.com/article/drought-and-climate-change-could-throw-fallcolors-off-schedule/. 2018

Thornhill J (2019) Flight shaming is taking off - can travel be more ethical? The Guardian. https://www. theguardian.com/money/2019/jun/09/flight-airline-travel-rail-family-environment. 2019

Tuohy J, Lindquist D, Briggs J (2018) Nearly 200 treated as temperatures just miss record high at Indy 500, Online edn. Gannett Company, Indianapolis

Tuohy J (2012) Rewind: state fair stage collapse: whose call was it? Star Media Indianapolis, Indiana 
Turton S et al (2010) Developing an approach for tourism climate change assessment: evidence from four contrasting Australian case studies. J Sustain Tour 18:429-447. https://doi.org/10.1080/09669 581003639814

UNWTO (2010) International Recommendations for Tourism Statistics. United Nations Dept of Economic and Social Affairs, United Nations World Tourism Organization,

USGCRP (2017) Climate Science Special Report: Fourth National Climate Assessment, Volume I. U.S. Global Change Research Program. https://doi.org/10.7930/J0J964J6

van der Wiel K, Kapnick SB, Vecchi GA (2017) Shifting patterns of mild weather in response to projected radiative forcing. Clim Change 140:649-658. https://doi.org/10.1007/s10584-016-1885-9

van Hoose N (2016) Through the grapevine: weathering climate change - Indiana warms up to wine grapes. Department of Agricultural Communications, College of Agriculture, Purdue University. https://ag. purdue.edu/foodsci/extension/winegrapeteam/WineteamDocuments/through-the-grapevine.pdf. 2018

VHC Grand Park: the sports campus at Westfield. Visit Hamilton County Indiana. https://www.visithamil toncounty.com/sports/grand-park/. Accessed 091920202020

Widhalm $M$ et al (2018) Indiana's past and future climate: a report from the Indiana climate change impacts asessment. Purdue Climate Change Research Center, Purdue University, West Lafayette, Indiana. https://doi.org/10.5703/1288284316634

Widhalm M, Dukes J (2020) Introduction to the Indiana climate change impacts assessment: overview of the process and context (Supplemental Table 1: Database of State Climate Assessments) Climatic Change 163:1869-1979

Xie Y (2016) Phenological responses of deciduous woody plants to climate variability and change from individuals to communities. University of Connecticut

Yardley J, Sigal RJ, Kenny GP (2011) Heat Health Planning: the Importance of Social and Community Factors Global Environmental Change 21:670-679. https://doi.org/10.1016/j.gloenvcha.2010.11.010

YCC-Team (2020) Indiana city turns flood-prone properties into a riverside trail system. Yale Center for Environmental Communication. https://yaleclimateconnections.org/2020/09/indiana-city-turns-floodprone-properties-into-a-riverside-trail-system/. Accessed 2/11/2021

Publisher's note Springer Nature remains neutral with regard to jurisdictional claims in published maps and institutional affiliations. 